\title{
403 凹凸路を走破する歩行支援機の動力学設計
}

\section{Dynamic Design of a Walking Aid for Rough Road Surfaces}

$\begin{aligned} & \text { O正 } \text { 石濱 } \\ & \text { 正男 (神奈川工大) 学 有竹 貴司（神奈川工大） }\end{aligned}$

Masao ISHIHAMA, Kanagawa Institute of Technology, 1030Shimo Ogino, Atsugi-shi, Kanagawa-ken Takashi ARITAKE, Kazuyuki SAKAMOTO, Toshihiro NAKAGOSHI, Kanagawa Institute of Technology

\begin{abstract}
A prototype of walking aid for riding over gaps and rough road surfaces was developed. To ride over gaps easily, it adopted virtual large diameter wheel concept that consists of multi small diameter wheels placed on the virtual wheel circumference, in combination with soft front suspension compliance. Giving the frame high stiffness by FEM topological and parametrical optimization minimized structural vibration amplification; and. reduced the vibration transmission to human hands with minimum weight. In addition, vibration isolation mechanisms were installed at the handle linkages and at the grips. This design was, however simple, proved to be effective through objective and subjective evaluation tests.
\end{abstract}

Key Words: Dynamics, Design, Vibration, Walking Aid, Ride, Road

\section{A1. はじめに}

ちょっとした段差や不整路を乗越えての散歩や買い物が できる, 安価な歩行支援機を, 本体構造や足回りの動力学的 検討を多用して試作機の開発を行った。

\section{A2. 製品の企画}

A2.1 想定する使用者 : 軽度の歩行機能障害者や高齢者.

A2.2 主な仕様

駆動： 後輪を想定

操舵： 前輪キャスター式

旋回性能: $0.9 \mathrm{~m}$ 以下

段差乗越え高： $50 \mathrm{~mm}$

必要推進力 (人力) : $<128 \mathrm{~N}$

グリップ部振動 : $<5 \mathrm{~m} / \mathrm{s}^{2}$

支持剛性：たわみ<10mm

実用登坂角度 : $10^{\circ}$

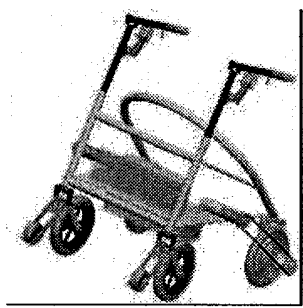

Fig.A1 CAD model of the walking aid prototype

\section{A3.1 本体構造案の創出}

\section{A3. 軽量化のための構造最適化}

歩行や足回りなどに必要な空間を除いた, 平面図でコの字 型の空間を，本体構造が使えると仮定し，均質化法有限要素 モデルで満たした。最適化計算の結果, サッカーゴール状の フレーム構造が最適構造案として残った.

\section{A3.2 フレーム構造の最適化}

均質化法で得られた最適形状と等価な断面2次モーメント を有する鋼管を配置した構造を設計し, 最低次の固有振動数 $(56.1 \mathrm{~Hz}$ ，ねじり）でも路面振動入力主要成分に対して十分 高いことを確認した。

\section{A4. 段差乗越え機構の開発}

\section{A4.1 多輪包絡線による仮想大径前輪の設計}

段差乗り上げに必要な力と前輪直径との関係を実験・計算 両面で検討した。人が楽に押せ，歩行器が前倒れしないため には段差の 10 倍の直径が必要となる．仕様を満たす $\phi 500$ の前輪は空間的制約により採用困難である。 そこで多数の車 輪配列の包絡線を仮想の大径輪として使う多輪包絡線の概 念を創出し, 摇動リンクの末端に小径輪を配置して, 仮想直 径 740mm を実現した. リンクの摇動は, 予荷重を与えたね じりばねで反力を与え, 通常走行中の安定と, 段差乗越え時 の衝撃吸収の両作用を持たせている.
A4.2 段差乗越え運動シミュレーション

機構解析ソフトウェアを用いて，日常生活範囲で頻度が高 い $50 \mathrm{~mm}$ 段差乗越え運動の時系列解析を行い, 最大荷重, 加 速度などを予測し，問題のないことを確認した。
19<smiles>c1ccccc1</smiles>

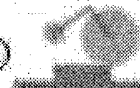<smiles>[O-]</smiles>

6
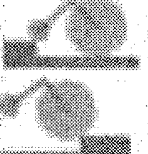

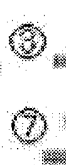

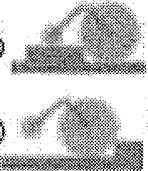

(4)

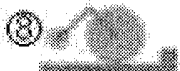

Fig.A2 Animated bump override simulation

A4.3 プロトタイプによる作用力の実測

被験者が握るグリップとフレーム間にカセンサーを挟み, 前後と上下方向の力を計測した結果, 必要推進力は $170 \mathrm{~N}$ で あった. 補助駆動力として $42 \mathrm{~N}$ を得られれば, 日常生活上必 要な段差の殆どを乗越え可能であることが証明された。

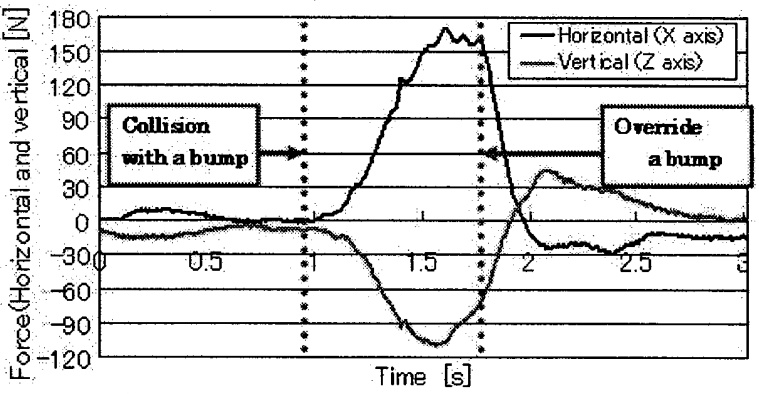

Fig.A3 Measured grip forces at a $50 \mathrm{~mm}$ bump

\section{A4.4 ハンドルとグリップ部の防振設計}

前輪の摇動リンクだけでは遮断できない上下振動は, ハン ドルを摇動させてばねで吸収, 前後振動はグリップのスライ ド機構とばねで吸収した。

\section{A5． 実走行での第三者による感性評価}

高齢者キットを着用した模擬歩行障害者 14 名による評価 の結果, 既存の歩行車よりも段差昇降性がすぐれることが確 認された. しかし, 乗り上げ直後の前輪サスペンションばね の反動による加速に違和感が残った. 駆動補助とともに今後 の課題である. 


\section{1.はじめに}

「夢ある老後」の実現には，身体機能の維持・回復を通じ て高齢者の社会参加促進が重要である。このためには，歩行 による自立生活での上下肢の訓練が重要であり，それに役立 つ歩行支援機の研究開発，実用化が課題となっている。 しか し，従来型の歩行補助車は，ちょっとした段差や不整路での 走行が困難である. 本研究では,「段差乗越え」,「転倒防止」, 「手腕への振動伝達防止」という動力学的性能を向上し, 生 活行動範囲の拡大を保証し得る走行性能を持つ歩行支援機 の設計技術開発を行った。

\section{2. 製品の想定と企画}

\section{1 生活道路走行による必要性能調査}

神奈川工科大学周辺の住宅と商店街約 $5 \mathrm{~km}$ を，市販の歩 行支援機を使って歩き, 問題となる路面・段差調査を行った. この支援機は，前後輪ともに直径 $200 \mathrm{~mm}$ の車輪を有し，前 輪がキャスターになっているもので, 病院の廊下などの平坦 路面での使用を前提として設計されている．調査にはビデオ 収録，物差しでの段差高さ測定，歩行支援機の車軸取付け点 での加速度計測などの方法を用いた. この段差高さの頻度分 析結果を Fig.1 に示す.

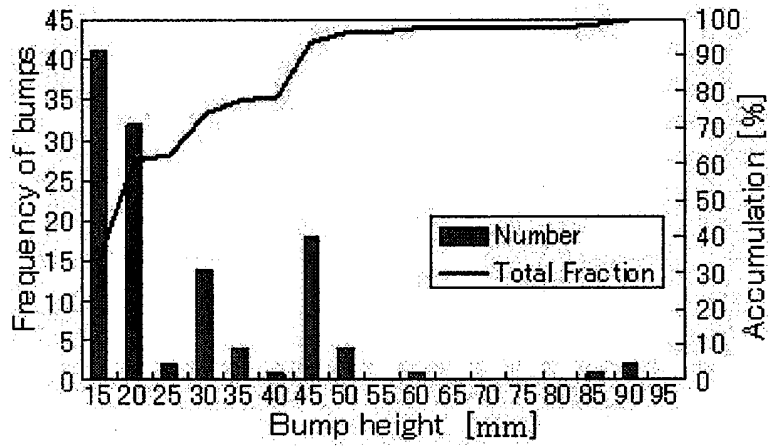

Fig.1 The bumps distribution investigation result

段差の出現累積頻度 95\%の範囲は 50mmに相当する。ま た, 歩行安全上最も重要と考えられる横断歩道から歩道へ上 るときの段差を構成する縁石がこの高さである．従って $50 \mathrm{~mm}$ 段差をクリアできれば通常の支障はなくなる。また， 点字タイルやグレーチング上でフレームの弾性共振を伴う 不快な振動を感じた．典型的な凹凸路での車軸振動の計測結 果は約 $15 \mathrm{~m} / \mathrm{s}^{2}$ であった．以後，このデータベースを設計に 用いた。

\section{2 想定する使用者}

運動機能が低下した高齢者, あるいは歩行機能に軽度の障 害を持つ歩行障害者.

\section{3 支援する歩行条件}

既存歩行車の段差・不整路での進行不能状態を改善し，屋 外での移動を支援する．段差や荒れた路面上の歩行を想定。

\section{4 主な仕様}

（1）重量 : $15 \mathrm{~kg}$ 以下（重心高 : $300 \mathrm{~mm}$ 以下）

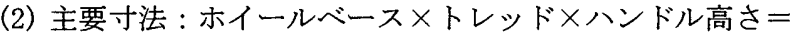
$500 \times 520 \times 800 \mathrm{~mm}$

（3）駆動方式 : 後 2 輪ベルト駆動（将来装着. 今回の試作機 には駆動装置は装着していない.)

(4) 制動方式：手動及び ER 流体ブレーキ

（5）制御方式：無段階速度調整式（力, 変位センサ）
（6）実用登坂角度 : $10^{\circ}$

（7）段差乗越え高さ：50mm

（8）上下・前後加速度 : グリップ部で $5 \mathrm{~m} / \mathrm{s}^{2}$ 以下

（9）姿勢変化：支援時に $10 \mathrm{~mm}$ 以下のたわみ量

(10) 操舵方式： 前 2 輪キャスター式（注 1)

注 1.エレベータ内や人ごみでは，小回り（自転）が効か ないと持ち上げなければならない，そこで，ほぼ自 転可能である 2WS と 4WS を検討した (Table 1, Fig2) . 4WS は機構が複雑になる。モータ一取付け が容易な後輪固定の 2 WS を採用した.

Table.1 Comparison of turning radius (2WS and 4WS)

\begin{tabular}{|c|c|}
\hline $2 \mathrm{WD}\left(\mathrm{R}_{\mathbf{2 W S}}\right)[\mathrm{m}]$ & 0.82 \\
\hline $4 \mathrm{WD}\left(\mathrm{R}_{\mathbf{4 W S}}\right)[\mathrm{m}]$ & 0.53 \\
\hline$\left(\mathrm{R}_{\mathbf{4 W S}} / \mathrm{R}_{\mathbf{2 W S}}\right) \times 100[\%]$ & 64.5 \\
\hline
\end{tabular}

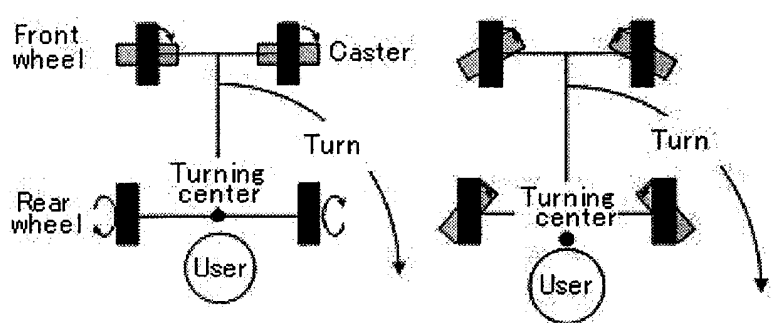

Fig.2 Turning geometry. 2WS (left), 4WS (right)

(11)ヒューマンインターフェイスの位置

既存歩行車の利用率は, 女性が圧倒的に多い。機器の寸法 決定には, 被支援者の身長・横幅・上肢長及び下肢長, 下肢 機能，上肢筋力，姿勢を用いた。(Fig.3,4参照)

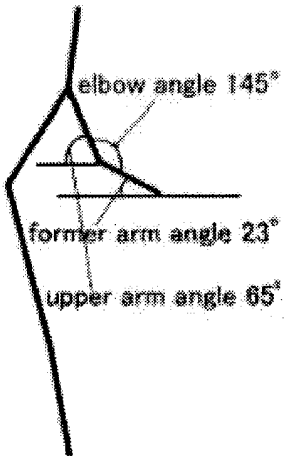

Fig.3 Optimum support angle in vertical plane

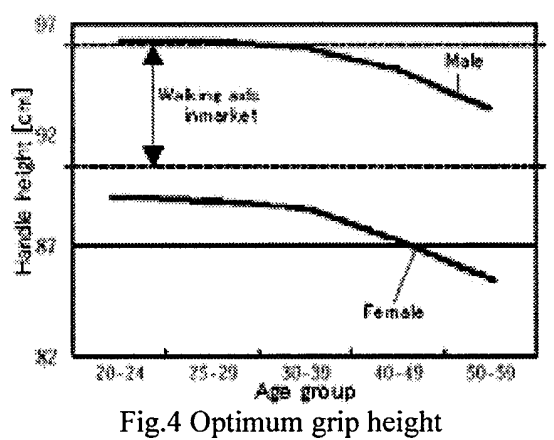

3. 軽量化のための構造最適化

3.1 本体構造案の創出

歩行や足回りなどに必要な空間を除いた, 平面図でコの字 
型の空間を, 本体構造が使えると仮定し，均質化法有限要素 モデルで満たした．最適化を行う条件としては，まず静的な 荷重を考え，下記の 3 条件を満足させた. 計算の結果, サッ カーゴール状のフレーム構造が最適構造案として残った.

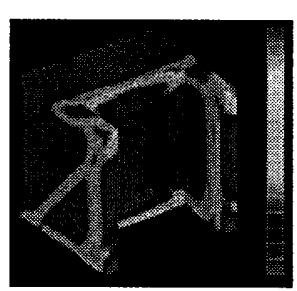

(Fig.5)

《最適化条件》 (※)

(1) 静止時, 使用者体重の $40 \%$ 支援時

(2) 前輪の障害物衝突時

(3) 傾斜地にて使用者の体重を機器 で支援

Fig.5 Strain energy distribution during topology optimization process. High strain portions were kept as structural members.

さらに Fig.5 を基に力法によるノンパラメトリック形状最 適化法を用い，必要な骨格を抽出し（Fig.6），上記の最適化 条件 (※) にて形状最適化を行った（結果：Fig.7）。
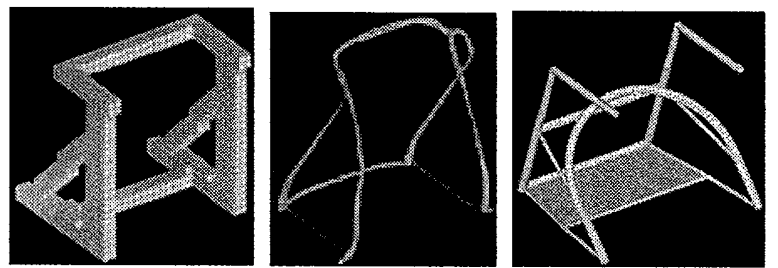

Fig.6 Topologically optimized model (left)

Fig.7 Shape optimized model (middle)

Fig.8 Model for realization (right)

\section{2 フレーム構造の最適化}

フレームが路面入力を増幅して手腕系に伝達せず, 荒れた 路面を快適に歩くには，まずフレームの剛性を上げて，固有 振動数を高める必要がある. 均質化法で得られた最適形状と 等価な断面 2 次モーメントを有する鋼管を配置した構造を設 計した. (Fig.8) 最低次の固有振動数 $(56.1 \mathrm{~Hz}$ ，ねじり) でも 路面振動入力主要成分に対して十分高いことを確認した。 (Table 2)

Table 2 Mode shapes and natural frequencies

\begin{tabular}{|c|c|c|c|}
\hline \multirow{2}{*}{ Number } & Optimized & Conventional & \multirow{2}{*}{ Mode shape } \\
\cline { 2 - 3 } & Frequency $[\mathrm{Hz}]$ & Frequency $[\mathrm{Hz}]$ & \\
\hline 1 & 56.1 & 16.2 & Tosional vibration (Hor izontal) \\
\hline 2 & 63.8 & 21.3 & Opening and closing (Horizontal) \\
\hline 3 & 70.8 & 38.2 & Opening and closing (Hor izontal) \\
\hline 4 & 75.7 & 42.9 & Opening and closing (Vertical) \\
\hline
\end{tabular}

\section{4. 段差乗越え機構の開発}

\section{1 多輪包絡線による仮想大径前輪の設計}

段差乗り上げに必要な力と前輪直径との関係を，準静的な 運動を行うとして計算で検討した。(Fig.9)

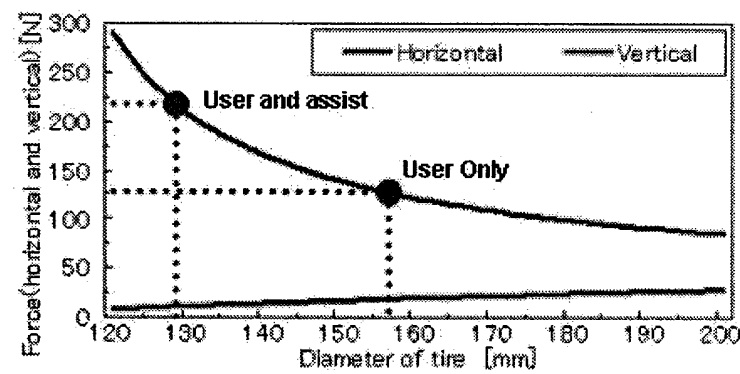

Fig.9 Required amount of forces to override a $50 \mathrm{~mm}$ bump
この計算による傾向を基礎として,タイヤの変形や軸受け の影響を含めた供試品(Fig.10,11)を用いて実験を行ったとこ ろ, 人が楽に押せ, 歩行器が前倒れしないためには段差の 10 倍の直径が必要となることがわかった。 (Table 3)

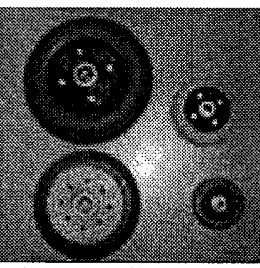

Fig. 10 Solid tires

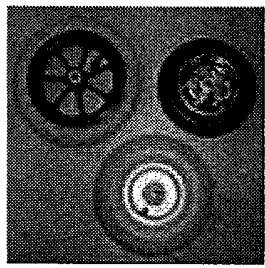

Fig.11 Pneumatic tires
Table3 Permissible bump height of each tires

\begin{tabular}{|c|c|c|c|c|c|c|}
\hline \multirow{2}{*}{ No. } & \multirow{2}{*}{ Specification } & \multicolumn{5}{|c|}{ Bumps height [mm] } \\
\hline & & 5 & 10 & 15 & 20 & 25 \\
\hline 1 & $\$ 200$ solid tire & 0 & 0 & 0 & 0 & 8 \\
\hline 2 & $\phi 150$ solid tire & 8 & 0 & X & 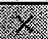 & 啭 \\
\hline 3 & $\phi 100$ solid tire & 0 & $x$ & 7 & X. & 8 \\
\hline 4 & $\phi 75$ solid tire & 0 & $x$ & 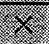 & 8 & \\
\hline 5 & $\$ 200$ pneumatic tire & 0 & 8 & 9 & 8 & 3. \\
\hline 6 & $\phi 165$ pneumatic tire & 0 & 0 & 8 & x & 3 \\
\hline 7 & $\phi 150$ pneumatic tire & 0 & 0 & 0 & 8 & 12 \\
\hline
\end{tabular}

仕様を満たす $\phi 500$ の前輪は空間的制約により採用困難で ある. そこで多数の車輪配列の包絡線を仮想の大径輪として 使う多輪包絡線の概念を創出し，摇動リンクの末端に小径輪 を配置して，仮想直径 $740 \mathrm{~mm}$ を実現した。 (Table 4, Fig.12, Fig.13)リンクの摇動は，予荷重を与えたねじりばねで反力を 与え, 通常走行中の安定と, 段差乗越え時の衝撃吸収の両作 用を持たせている。

Table 4 The main parts of link mechanism

\begin{tabular}{|c|c|}
\hline Parts list & Specification \\
\hline Caster for bearing & Single rom bear ing $600002 \mathrm{Z})$ \\
\hline Front small wheel for induction & $\phi 75$ solid tire \\
\hline Front normal wheel for running & $\phi 200$ pneumatic tire \\
\hline Mechanism for link parts & Torsion spring $(0.7 \mathrm{~N} \cdot \mathrm{m} / \mathrm{deg})$ \\
\hline Connecting mith frame & MT0 $\times P 1.5 \times 30 \mathrm{~mm}$ Bolt \\
\hline Material for link parts & Alminum $(\mathrm{Al}-5052)$ \\
\hline Bracket & Steel $(S S 400)$ \\
\hline
\end{tabular}

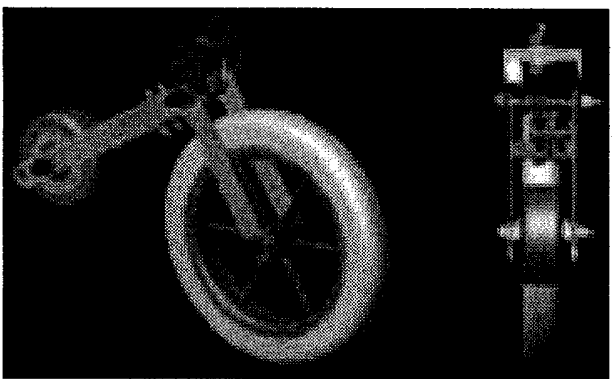

Fig.12 CAD model of front wheel link mechanism 


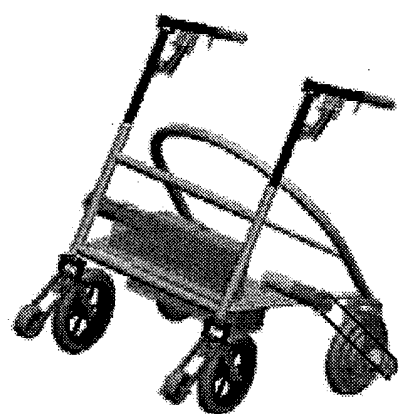

Fig.13 3D-CAD model of our walking aid

\section{2 前輪リンク方式の前方転倒安定性検討}

段差乗上げ時に前向きに大きな力を加えても, 前方への転 倒の恐れがないことを確認した. 前輪を支点に後輪が浮き上 がる現象検討に, 各種作用力ベクトルが 2 つの前輪軸まわり に作る合モーメントを計算する下記力学モデルを使用した.

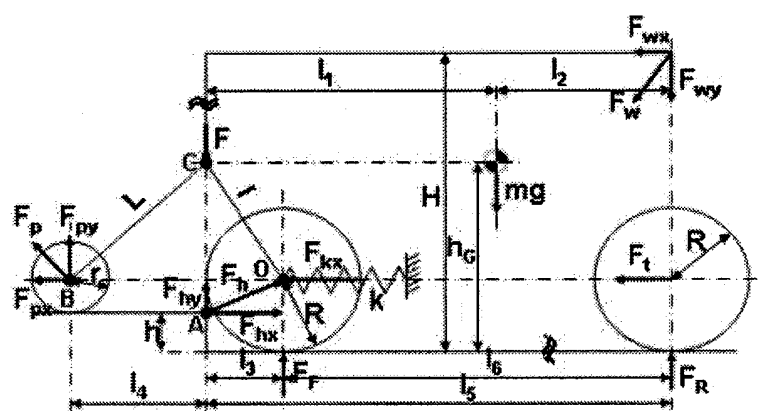

Fig.14 Dynamical model for dive stability

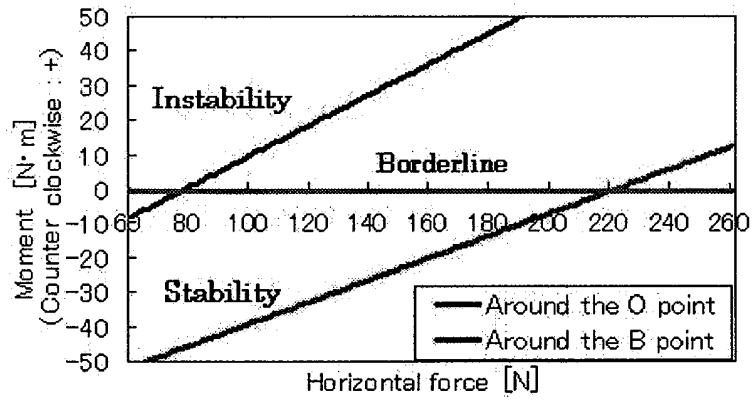

Fig. 15 Margin of dive stability ( $\mathrm{O}$ and $\mathrm{B}$ position)

Fig. 15 の上半分は不安定領域である. 小径車輪が前方で段 差上側で反力を返してくれるので, 重心高さ $300 \mathrm{~mm}$ とすると， 前方への転倒安定限界值は $220 \mathrm{~N}$ である. 高齢者の押す力は, 最大で $130 \mathrm{~N}$ であることから，信頼性を確保できている.

\section{3 段差乗越え運動シミュレーション}

機構解析ソフトウェアを用いて, 日常生活範囲で頻度が高 い $50 \mathrm{~mm}$ 段差乗越え運動の時系列解析を行い, 最大荷重, 加 速度などを予測し，問題のないことを確認した。
1

(5)
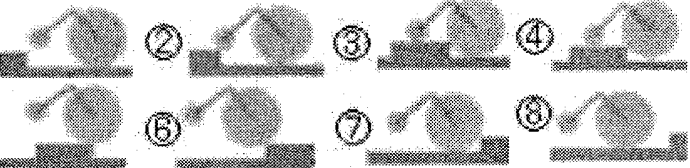

Fig.16 Animated front suspension bump override simulation
リンク機構に搭載されているトーションばねの定数を低 い值にすると段差を乗越え易い一方, 前輪がフワフワするた め, 支援性に劣る. 段差乗越え性・支援性の確保のため, 八 ンドル位置を後輪軸上に配置することで支援時の車体沈み 込みも抑えられた。 (Fig.17)

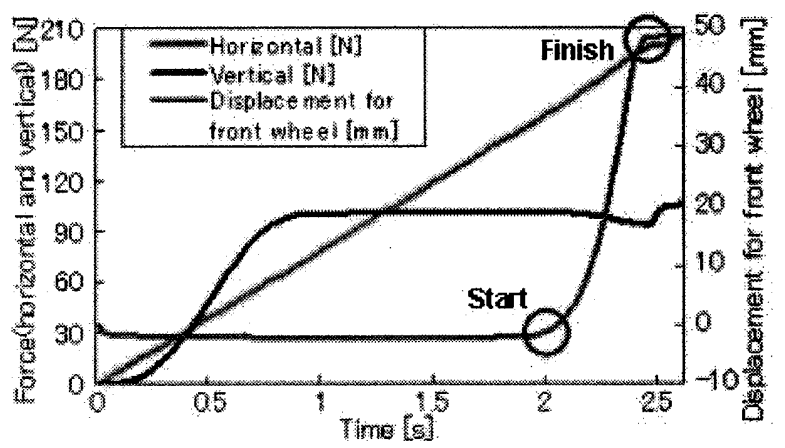

Fig.17 Calculated front axle displacement (green line) during the bump override motion

\section{4 プロトタイプによる作用カの実測}

被験者が握るグリップとフレーム間にカセンサーを挟み, 前後と上下方向の力を計測した結果, 必要推進力は $170 \mathrm{~N}$ で あった. (Fig.18) 高齢者が自力で押せる力を $128 \mathrm{~N}$ と設定す れば, 補助駆動力として 42N を得られれば, 日常生活上必要 な段差の殆どを乗越え可能であることが証明された。

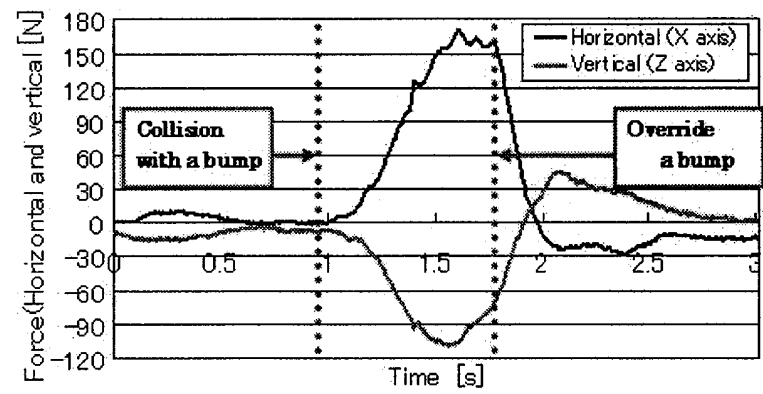

Fig. 18 Measured grip forces at a $50 \mathrm{~mm}$ bump

\section{5 ハンドルとグリップ部の防振設計}

前輪の摇動リンクだけでは遮断できない上下振動は, ハン ドルを摇動させてばねで吸収する構造とし，前後振動はグリ ップのスライド機構とばねで吸収した.(Fig.19,20) 目標振動 レベルは電磁 加振器を正弦波駆動して手で感性評価し, 不 快となる振幅をオクターブ中心周波数毎に設定した。

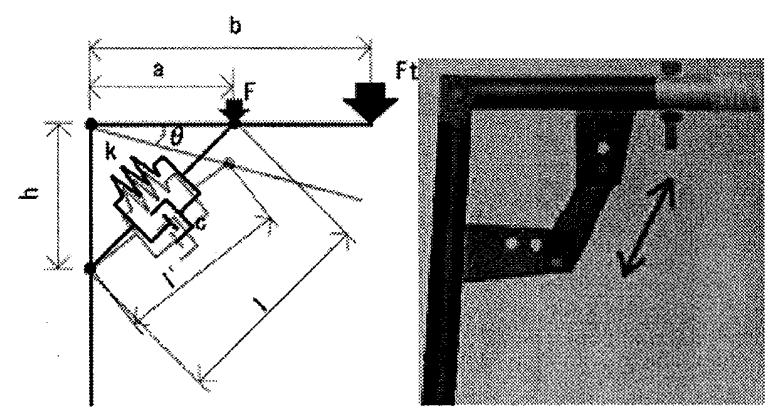

Fig.19 Dynamical model of handle and suspension linkage (left) and its CAD model (right) 


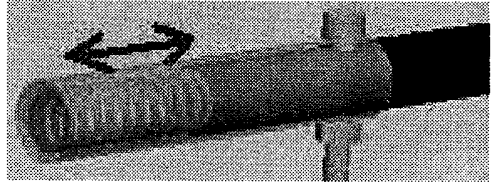

Fig.20 Grip and built-in spring for vibration isolation

これらの防振機構の性能を段差昇降実験にて測定した結 果, 各周波数帯の振動レベルが, 目標值 $(125 \mathrm{~Hz}$ のみ許容 值）内に収まる事を確認した（Fig.21）。図中，上側の折れ線 グラフは手に加わる振動加速度の許容最大振幅，下側はその 理想値である。

\section{5．被験者による総合感性評価}

\section{1 実験方法}

第三者に段差昇降性や振動吸収性などの比較・評価をして頂 いた。評価項目を以下に示す。

(1) Oscillation performance（振動の感じ易さ）

(2) Override bumps（段差の乗越え易さ）

(3) Turning behavior（曲がり易さ）

(4) Running through performance（凸凹路面の走り易さ）

(5) Overall performance（総合評価）

- 評価対象者： 20 代前半の学生 14 名. 歩行障害者を模擬 するために，高齢者キットを装着. (Fig.22)

・供試歩行支援機 :

$\mathrm{A}$ ：従来品（コスモネティ社製）

B: 開発品. 前輪リンク式サスペンション付, NW-1 型. 八 ンドルサスペンションとグリップばねは無い状態. (Fig.23)

\section{2 評価の結果}

前輪に段差乗越え用摇動リンクを用いた開発品の段差昇 降性は，既存歩行車よりも優れる結果を得た。振動特性につ いて従来品と同じ評価しか得られていないのは, ハンドルと グリップ分の防振構造を除いて実験をしたためである.しか し, 乗上げた時に一旦トーションバネにエネルギが蓄積され，
その後に反動で前に勢い良く動くことが難点と評価された
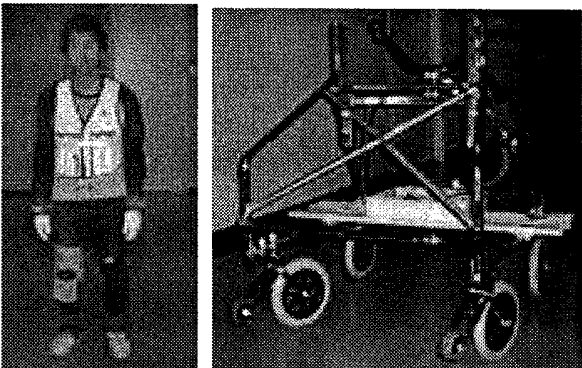

Fig.22 A subject with a senior citizen kit (left)

Fig.23 Walking aid with the developed front wheel mechanism

\section{6. 結論}

段差乗越えを容易にする安価な歩行支援機の動力学的設 計を行い，試作・実験をした結果，駆動制御を除くパッシブ 系について所定の機能・性能を有するものを開発することが できた.

多輪包絡線による仮想大径輪という設計概念を創出し，小 径タイヤ2輪及びリンク機構を組み合わせる事でコンパクト に具現化し, 目標値として定めた $50 \mathrm{~mm}$ 段差を乗越える事を 実証した。

\section{7. 参考文献}

(1) 宗安淮一郎，路面傾斜角度を考慮したアシスト歩行支援 機の開発，平成 16 年度芝浦工業大学修士論文

(2) 新エネルギ産業開発総合機構報告書, 高齢者生活作業支 援システム株式会社日立製作所・機械研究所実施,

（3）彦根貴司，歩行支援機の動力学的設計，平成 16 年度神奈 川工科大学大学院修士論文
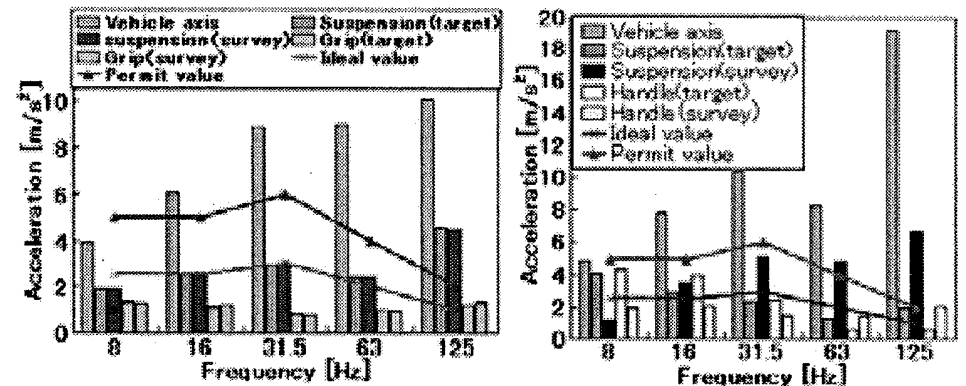

Fig.21 Measured vibration acceleration amplitudes in back and forth direction (left) and vertical direction (right).

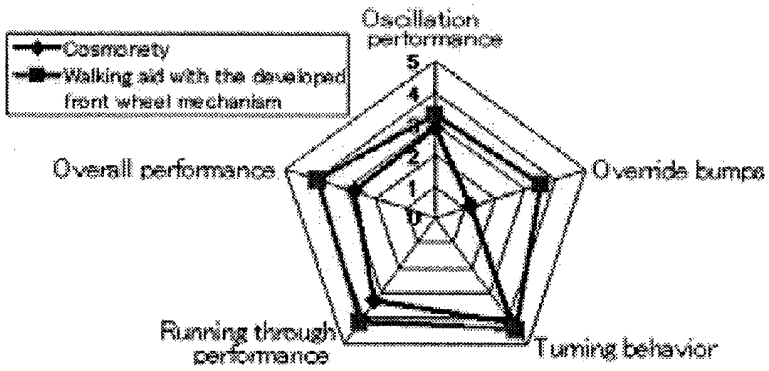

Fig.24 Result of subjective evaluations 